\title{
POLOŽAJ OŠTEĆENIKA U ADHEZIJSKOM POSTUPKU
}

\author{
Doc. dr. sc. Mijo Galiot* \\ Vanesa Brizić Bahun, dipl. iur.**
}

\author{
UDK 343.122:347.426 \\ https://doi.org/10.30925/zpfsr.42.2.11 \\ Ur.: 30. ožujka 2021. \\ Pr.: 2. svibnja 2021. \\ Pregledni rad
}

\begin{abstract}
Sažetak
Rad se bavi položajem oštećenika u postupku koji se pokreće prijedlogom za ostvarivanje imovinskopravnog zahtjeva u sklopu kaznenog postupka. Imovinskopravni zahtjev, kao sporedni predmet građanske naravi koji je pridružen kaznenom postupku, naziva se adhezijskim postupkom i predstavlja specifičnu mješavinu kaznenog i građanskog prava. Vođenje toga postupka izraz je načela ekonomičnosti, ali i nastojanja da se izbjegne dvostruko suđenje u istoj stvari. U prvom se redu govori o pojmu i pravnoj prirodi instituta te se u nastavku obrađuju neke njegove bitne značajke i to posebno pitanje subjekata postupka i pretpostavke za njegovo vođenje, u odnosu na procesni položaj oštećenika koji bi i s obzirom na zakonodavno rješenje i praksu hrvatskih sudova trebao biti primjereniji. Zbog toga se autori zalažu da se pri noveliranju kaznenog procesnog zakonodavstva više pažnje posveti oštećeniku i imovinskopravnom zahtjevu koji bi trebalo sustavnije urediti, pritom vodeći računa o njegovim posebnostima. U tom smislu se ukazuje na pojedina sporna pitanja te se predlažu moguća rješenja. Ističe se i da je položaj oštećenika potrebno poboljšati kako bi imao sva prava kao da je svoj zahtjev postavio u parnici.
\end{abstract}

Ključne riječi: oštećenik; imovinskopravni zahtjev; adhezijski postupak; naknada štete.

\section{1. $U V O D$}

Počinjenje kaznenog djela najčešće ne dovodi samo do povrede općega društvenog interesa $\mathrm{i}$ javnog poretka već i do povrede zaštićenih dobara određene osobe. Zaštićena dobra su osobna ili imovinska prava koja se u pravnoj teoriji nazivaju subjektivnim pravima. Svako subjektivno pravo ima svoga nositelja te takvom pravu nužno odgovara obveza drugoga subjekta. ${ }^{1}$ Ako je riječ o povredi subjektivnih prava

* Dr. sc. Mijo Galiot, docent, sudac Općinskog suda u Splitu; galiot1305@gmail.com. ORCID: https://orcid.org/0000-0003-4835-0555.

**VVanesa Brizić Bahun, dipl. iur., sutkinja Općinskog građanskog suda u Zagrebu; vanesa.brizic@ gmail.com. ORCID: https://orcid.org/0000-0003-0519-1232.

1 Mladen Vedriš i Petar Klarić, Građansko pravo: Opći dio, stvarno pravo, obvezno i nasljedno pravo (Zagreb: Narodne novine, 2003.), 65. 
do koje je došlo počinjenjem kaznenog djela, na jednoj strani se nalazi osoba čije je subjektivno pravo povrijeđeno, dakle, oštećena osoba koju ćemo u nastavku zvati oštećenik. Na drugoj je strani osoba koja je kazneno djelo počinila koju ćemo, iako u različitim etapama kaznenog postupka ima različite nazive (osumnjičenik, okrivljenik, optuženik, osuđenik), zbog jednostavnosti nazivati okrivljenik.

Pravo na zaštitu povrijeđenih ili ugroženih subjektivnih prava jedno je od temeljnih prava osobe oštećene počinjenjem kaznenog djela, a upravo je pružanje te zaštite jedna od bitnih funkcija države. S obzirom na to da se o počinjenju kaznenog djela raspravlja u kaznenom postupku, a o zaštiti povrijeđenih ili ugroženih subjektivnih prava u pravilu u građanskom postupku, jasno je da isti događaj može istodobno biti predmet raspravljanja u građanskom i kaznenom postupku. Stoga se logično nametnulo pitanje bi li se zaštita povrijeđenih ili ugroženih subjektivnih prava trebala pružati i u sklopu kaznenog postupka. Pri tom je nužno istaknuti kako je povijesno prevladavala uloga oštećenika u kaznenom postupku. No, razvojem suvremenoga kaznenog postupovnog prava država je u gotovo svim poredbenim pravnim sustavima ponajviše na sebe preuzela obvezu pokretanja kaznenog postupka, dok je oštećenicima znatno suzila njihove procesne mogućnosti u tom postupku. ${ }^{2}$

Sudu u kaznenom postupku nije najvažnije pitanje pružanje zaštite povrijeđenim ili ugroženim subjektivnim pravima pojedinaca, već zaštita općeg društvenog interesa. ${ }^{3}$ Međutim, to je iznimno važno za osobu koja je počinjenjem kaznenog djela pretrpjela štetu i koja zbog toga ima imovinskopravni zahtjev. Stoga oštećeniku treba dati primjeren položaj u kaznenom postupku neovisno o tome što je opće stajalište doktrine da se njegova tražbina nastala zbog počinjenoga kaznenog djela smatra sporednim predmetom kaznenoga postupka.

Svjedočimo čestim izmjenama brojnih zakona osobito onih koji sadrže procesna pravila kako bi se postupci ubrzali i kako bi se postigla najveća učinkovitost i koncentracija raspravljanja. Tako je i Zakon o kaznenom postupku, koji je kao rezultat najavljivane velike reforme kaznenog postupka stupio na snagu 2008., do danas već devet puta izmijenjen, ${ }^{5}$ a neke su se izmjene odnosile i na položaj oštećenika. Stoga je nužno analizirati navedene odredbe i njihove izmjene, ali i konkretna rješenja sudske prakse, utvrditi i ocijeniti kakav je procesni položaj oštećenika u kaznenom postupku, omogućava li mu se na odgovarajući način zaštita njegovih povrijeđenih ili ugroženih subjektivnih prava te utvrditi mogućnosti poboljšanja njegova položaja u kaznenom postupku u povodu njegova imovinskopravnog zahtjeva. Razlog tomu je što bi to dovelo do smanjenja predmeta koji se rješavaju u parničnom postupku, a da istodobno ne bi došlo do otežavanja osnovne svrhe kaznenog postupka i njegove učinkovitosti.

2 V. Eduard Kunštek, „Actio civilis u kaznenom postupku - prijedlog novele“ u: Zbornik radova, Deset godina rada Zavoda za kaznene znanosti Mošćenice Pravnog fakulteta Sveučilišta u Rijeci (Rijeka: Pravni fakultet Sveučilišta u Rijeci, 2008.), 206, https://www.yumpu.com/it/ document/read/18209553/decennium-moztanicense.

3 Kunštek, Actio civilis u kaznenom postupku, 207.

4 Zakon o kaznenom postupku, Narodne novine, br. 152/08., 76/09., 80/11., 121/11., 143/12., 56/13., 145/13., 152/14., 70/17., 126/19. (dalje: ZKP/08).

5 Zakoni o izmjenama i dopunama Zakona o kaznenom postupku objavljeni su u Narodnim novinama, br. 76/09., 80/11., 121/11., 143/12., 56/13., 145/13., 152/14., 70/17. i 126/19. 
Čini se kako i nakon svih izmjena i dopuna ima prostora za poboljšanje položaja oštećenika. Naime, i nadalje se prema zakonodavnom rješenju, ali i praksi hrvatskih sudova, oštećenik nalazi u neprimjerenom položaju, što se posebno odnosi na njegovu ograničenu mogućnost osporavanja odluke kada sud odluči ne raspravljati o njegovu zahtjevu, nemogućnosti izjavljivanja izvanrednih pravnih lijekova protiv odluke suda, onemogućavanja inicijalnog postavljanja zahtjeva univerzalnih ili singularnih sukcesora oštećenika i dr.

\section{POVIJESNI RAZVOJ}

Povijesni razvoj kaznenog postupka tekao je od shvaćanja o kaznenom djelu i kaznenom postupku kao privatnoj stvari stranaka, do kaznenog djela i kaznenog postupka shvaćenih kao stvari javnoga poretka. ${ }^{6}$

U razvoju rimskog prava vidljivo je jasno razlikovanje između kaznenih djela koja su ponajprije vrijeđala ili ugrožavala subjektivna građanska prava tih osoba (lat. delicta privata) i kaznenih djela kojima se vrijeđao javni interes (lat. delicta publica). ${ }^{7}$ Posebno su područje bili odnosi u obitelji u koje se država u pravilu nije miješala i u kojima je kaznenu vlast vršio pater familias (dugo pravno neograničenu). ${ }^{8}$ Kada je bila riječ o tzv. delicta privata kojima bi oštećeniku bila nanesena šteta, kažnjavanje je imao pravo tražiti upravo on, a ne država. Kazna se sastojala u obvezi okrivljenika da oštećenom isplati određeni iznos novčane vrijednosti koji je znatno prelazio stvarnu štetu i izricala se u građanskom postupku. ${ }^{9}$ Ako je kaznenim djelom bio povrijeđen javni interes postupak je pokretalo posebno tijelo, a kasnije je to pravo pripadalo bilo kojem rimskom građaninu, a ne samo oštećeniku. ${ }^{10} \mathrm{~S}$ vremenom se počelo smatrati kako sva kažnjiva djela vrijeđaju i javne interese te ih se počelo kažnjavati i javnim kaznama. No, oštećeniku je ipak bio ostavljen izbor počinitelja progoniti pred građanskim ili pred kaznenim sudom. ${ }^{11}$

U helenističko doba kazneno pravo je više predstavljalo područje društva i pojedinca nego države kao institucije. Tako je i inicijativa za gonjenje zbog povreda prava ostavljena volji građana. Oštećenik je mogao umjesto suda izabrati: izvansudsko poravnanje odmazdom ili novčanom naknadom ili privatnu arbitražu. ${ }^{12}$ Atensko pravo poznaje dvije vrste postupaka: dike (privatni postupak) i graphe (javni postupak). Privatni postupak pokretao je oštećenik kada je povrijeđen njegov privatni interes

6 Berislav Pavišić i suradnici, Kazneno postupovno pravo, 3. izd. (Rijeka: Pravni fakultet Sveučilišta u Rijeci, 2010.), 46.

7 Više Kunštek, Actio civilis u kaznenom postupku, 204.

8 Vladimir Bayer, Kazneno procesno pravo - odabrana poglavlja, Knj. 2., Povijesni razvoj kaznenog procesnog prava (Zagreb: Ministarstvo unutarnjih poslova Republike Hrvatske, 1995.), 3.

9 Kunštek, Actio civilis u kaznenom postupku, 204.

10 Vidi u Bayer, Kazneno procesno pravo, 4.

11 Bayer, Kazneno procesno pravo, 3.

12 Samo srodnici imaju pravo na privatnu odmazdu i na nagodbu o naknadi štete, dok treći moraju iznijeti predmet pred sud, v. više Šefko Kurtović, Opća historija države i prava, Knj. 1. (Zagreb: Narodne novine, 1990.), 112. 
neovisno o tome je li došlo do povrede javnog interesa i o njezinoj jačini. Sam je snosio troškove toga postupka, ali mu je pripadala i dosuđena naknada koja je također svojom visinom bila oblik odmazde. Javni je postupak imao pravo pokrenuti bilo koji procesno sposoban građanin, ali u njemu nije mogao ostvariti pravo na imovinsku naknadu, osim ako je tužbu podigao radi zaštite fiskalnih interesa države kada mu je pripadalo pravo na postotak dosuđene svote. ${ }^{13}$

U Franačkoj državi (5.-10. stoljeće) prevladavalo je privatnopravno shvaćanje kaznenog prava te se postupak protiv okrivljenika pokretao isključivo na inicijativu oštećenika. Stranke su se mogle nagoditi i izvan suda, a ako bi predmet došao na sud, novčana kazna bila je skoro jedini oblik obeštećenja. Novčanu naknadu koju izriče sud, oštećenik u ranije vrijeme nije morao prihvatiti nego je mogao zahtijevati odmazdu, dok ju je kasnije morao prihvatiti. I tu je visina naknade zapravo značila odmazdu i ponekad potpuno imovinsko uništenje obitelji počinitelja. ${ }^{14} \mathrm{U}$ kasnijem srednjem vijeku u njemačkom pravu znatno je prošireno javnopravno shvaćanje kaznenog djela, iako je i nadalje bilo u pravilu moguće da se počinitelj nagodi s oštećenikom te da ne dođe do kaznenog postupka. U ovo doba dolazi i do razdvajanja građanskog postupka od kaznenog postupka. ${ }^{15} \mathrm{U}$ srednjovjekovnoj Engleskoj (11.-15. stoljeće) postupak je uglavnom pokretao neposredno oštećeni, a država je kazneno progonila samo ako je bila izravno oštećena ili ako je oštećenik propustio pokrenuti postupak, a bila je riječ o kaznenom djelu s kojim je povrijeđen javni interes. ${ }^{16}$

U engleskom pravu od 16. do 20. stoljeća dolazi do znatnog razvoja kaznenog postupka koji sad ima svojstvo spora između dvije ravnopravne stranke, premda tužitelj bio i kralj (država). Pritom kaznena osuda nije obvezivala građanski sud niti obrnuto. Stranke su obvezne nadoknaditi i štete iz delikta, ali kazneni sud ne ulazi u pitanje naknade štete, nego stranke upućuje na građansku parnicu. ${ }^{17}$ Razvojem kaznenog postupka u njemačkim zemljama potpuno nestaje kazneni progon kojega pokreću privatne osobe, a inkvizitorni kazneni postupak ostaje jedini oblik kaznenog postupka. Navedeno razdoblje traje do sredine 19. stoljeća kada ga zamjenjuje mješoviti kazneni postupak. ${ }^{18}$ Već u austrijskom kaznenom zakoniku postoje odredbe koje sudu nalažu obvezu odlučivati i o naknadi štete, a ako mu to nije bilo moguće tada uputiti oštećenog s privatnopravnim potraživanjem na redoviti građanski sud. ${ }^{19}$

U francuskom kaznenom postupku počevši od Ordonanse iz 1670. pa do Code d instruction criminelle iz 1808. posebno je važno uvođenje ustanove javnog tužitelja i usvajanje načela oficijelnosti pri pokretanju kaznenog postupka, dok uloga oštećenika

13 Detaljnije Kurtović, Opća historija države i prava, Knj. 1., 112-114. Kurtović tako navodi i da je imovinska korist koju bi mogao ostvariti tužitelj u graphe postupku radi zaštite državnih fiskalnih interesa potaknula pojedince da se skoro profesionalno bave podizanjem tužbe za povrede fiska. Vidi i Željko Bartulović, Povijest prava i države (I. dio - Opća povijest prava i države (Rijeka: Pravni fakultet Sveučilišta u Rijeci, 2014.), 46.

14 Kurtović, Opća historija države i prava, Knj. 1., 171; Bartulović, Opća povijest prava i države, 55-56.

15 Bayer, Kazneno procesno pravo, 36.

16 Kurtović, Opća historija države i prava, Knj. 1., 234.

17 Šefko Kurtović, Opća historija države i prava, Knjiga 2. (Zagreb: Narodne novine, 1990.), 74.

18 Bayer, Kazneno procesno pravo -odabrana poglavlja, 73.

19 Vidi Kunštek, Actio civilis u kaznenom postupku, 206. 
sve više slabi. ${ }^{20}$ Oštećenik nije mogao od suda zatražiti kažnjavanje počinitelja kaznenog djela, ali je mogao tražiti da se njemu dosudi naknada za pretrpljenu štetu. ${ }^{21}$

Prikazani smjer razvoja kaznenog postupka ukazuje na kontinuirano slabljenje uloge oštećenika, ali se ipak zadržava njegova mogućnost ostvariti naknadu štete u kaznenom postupku. Tek su suvremene koncepcije otvorile pitanje treba li žrtvi dati posebno mjesto u kaznenom postupku te je tendencija sve šireg priznavanja oštećenikovih prava ${ }^{22} \mathrm{i}$ to ne samo u odnosu na pravo na podnošenje imovinskopravnog zahtjeva već i u odnosu na kažnjavanje okrivljenika na što upućuju i odluke Europskog suda za ljudska prava (dalje: ESLJP). ${ }^{23,}{ }^{24}$

\section{ODNOS PARNIČNOG I KAZNENOG POSTUPKA}

Kada je riječ o zaštiti i ostvarenju subjektivnih (građanskih) prava govori se o građanskopravnim sporovima za koje se parnični postupak označava kao redoviti put pravne zaštite. ${ }^{25}$ Sud u parničnom postupku samostalno rješava sva pravna pitanja, pa i kaznenopravna, od kojih ovisi njegova odluka o glavnoj stvari, ako nadležni kazneni sud o tome još nije odlučio. ${ }^{26}$

Zadatak je sudova u kaznenom postupku osigurati da nitko nedužan ne bude osuđen, a da se počinitelju kaznenog djela izrekne kazna ili druga mjera uz uvjete koje predviđa zakon i na temelju zakonito provedenog postupka pred nadležnim sudom (čl. 1. ZKP/08). Glavni predmet kaznenog postupka može biti jedno ili više kaznenih djela za koja se protiv jednog ili više počinitelja vodi kazneni postupak, a o tome se raspravlja isključivo u kaznenom postupku. ${ }^{27}$

Razlika između ta dva postupka vidljiva je već iz njihovih predmeta i svrhe postupka. Brojne su i razlike i u samim pravilima postupka (isticanje svih bi prelazilo svrhu ovog rada) od kojih je za potrebe teme koja se obrađuje, odnosno zaštite subjektivnih prava u kaznenom postupku, nužno posebno upozoriti na razlike

20 Kunštek, Actio civilis u kaznenom postupku, 206.

21 Bayer, Kazneno procesno pravo, 129.

22 Davor Krapac, Kazneno procesno pravo, Knj. 1.: Institucije, 3. izd. (Zagreb: Narodne novine d,d, 2015.), 255.

23 U tom smislu je u presudi Beganović protiv Hrvatske od 25. lipnja 2009. (§56) navedeno da su za djelotvorno odvraćanje od teških čina poput napada na tjelesni integritet osobe, gdje se dovode u pitanje temeljne vrijednosti i bitni aspekti privatnog života potrebne učinkovite kaznenopravne odredbe. Pravna sredstva iz građanskog prava ne mogu se smatrati dovoljnima za ispunjenje obveza država ugovornica na temelju čl. 3. Konvencije za zaštitu ljudskih prava i temeljnih sloboda, Narodne novine, MU, br. 18/97., 6/99., 14/02., 13/03., 9/05., 1/06., 2/10. (dalje: Konvencija).

24 U presudi Butijer protiv Hrvatske od 04. lipnja 2020. (§57) ocijenjeno je kako je miješanje težilo legitimnom cilju u javnom ili općem interesu, odnosno zaštiti prava žrtava kaznenih djela na naknadu pretrpljene štete.

25 Čl. 1. Zakona o parničnom postupku, Narodne novine, br. 53/91., 91/92., 112/99., 88/01., 117/03., 88/05., 02/07., 84/08., 96/08., 123/08., 57/11., 148/11. (pročišćeni tekst), 25/13., 89/14. i 70/19. (dalje: ZPP).

26 Siniša Triva i Mihajlo Dika, Građansko parnično procesno pravo (Zagreb: Narodne novine, 2004.), 86 .

27 Pavišić, Kazneno postupovno pravo, 74. 
u odredbama o pokretanju postupka, izvođenju dokaza te predujmljivanju troškova postupka. $^{28}$

Dodirne točke između ta dva postupka dolaze do izražaja pri odlučivanju o prethodnim pitanjima, ${ }^{29} \mathrm{u}$ pravilima o vezanosti sudova za odluke drugih sudova ${ }^{30}$ te o imovinskopravnom zahtjevu. Sve to radi ekonomičnosti postupka i izbjegavanja kontradiktornih odluka. ${ }^{31}$

Odlučivanje o imovinskopravnom zahtjevu koji je rezultat štete počinjene kaznenim djelom i koji je postavljen u kaznenom postupku, kao pridruženi (adhezijski) postupak, je parnica u sklopu kaznenog postupka i stoga je specifična mješavina elemenata kaznenog i građanskog (parničnog) postupka. Sam je institut normiran odredbama XI. glave ZKP/08 i to čl. 153.-162. Prema odredbi čl. 153. ZKP/08 imovinskopravni zahtjev koji je nastao zbog počinjenja kaznenog djela raspravit će se na prijedlog oštećenika u kaznenom postupku, ako se time ne bi znatno odugovlačio taj postupak. Upravo se analizom mogućnosti i učinkovitosti ostvarivanja imovinskopravnih zahtjeva može najbolje ocijeniti kakav je uistinu položaj oštećenika u kaznenom postupku. Iako se u sklopu kaznenog postupka primjenjuju odredbe kaznenoga postupovnog zakonodavstva, oštećenik mora imati na raspolaganju sva pravna sredstva koja bi imao da je svoj zahtjev postavio u parnici, ${ }^{32}$ dok su materijalnopravne pretpostavke za donošenje odluke o imovinskopravnom zahtjevu obuhvaćene u propisima koji uređuju materiju građanskog prava. ${ }^{33}$

28 Kazneni postupak u pravilu se pokreće po službenoj dužnosti, dok pokretanje parničnog postupka ovisi o dispoziciji stranke. Kod izvođenja dokaza u parničnom postupku prevladava raspravno načelo, dok je u kaznenom istražno načelo prevladavajuće (iako ima i elemenata raspravnog načela). Troškove izvođenja dokaza u parničnom postupku u pravilu predujmljuje stranka koja ih je predložila, dok se troškovi izvođenja dokaza u kaznenom postupku isplaćuju iz sredstava tijela koje vodi kazneni postupak.

29 Doticaj između ove dvije grane pravosuđa ogleda se i u tome što odlučivanje o osnovanosti tužbenoga zahtjeva u parnici može zavisiti od rješenja nekog prejudicijelnog pitanja kaznenopravne naravi, o kojemu, kao o glavnom pitanju, odlučuju kazneni sudovi. I odlučivanje u kaznenom postupku može zavisiti od prethodnog rješavanja nekog prejudicijelnog pitanja građanskopravne naravi, za čije su rješavanje kao o glavnoj stvari inače nadležni sudovi u parničnom postupku. Triva i Dika, Građansko parnično procesno pravo, 86.

30 Čl. 12. st. 3. ZPP-a: U parničnom postupku sud je u pogledu postojanja kaznenog djela $i$ kaznene odgovornosti učinioca vezan za pravomoćnu presudu kaznenog suda kojom se optuženik oglašava krivim.

31 O vezanosti parničnog suda za presude kaznenog suda te izbjegavanju kontradiktornih odluka $\mathrm{u}$ istom pravnom sustavu vidi više u Triva i Dika, Građansko parnično procesno pravo, 87.

32 O tome v. Dinka Šago i Marija Pleić, „Adhezijsko rješavanje imovinskopravnog zahtjeva u kaznenom postupku“, Zbornik Pravnog fakulteta Sveučilišta u Rijeci, br. 2. (2012): 972, https:// hrcak.srce.hr/file.

33 Eduard Kunštek, „Imovinskopravni zahtjevi“, u: Berislav Pavišić, Komentar Zakona o kaznenom postupku, 5. izd. (Rijeka: Žagar, 2005.), 167. 


\section{STRANKE U POSTUPKU}

\subsection{Aktivna legitimacija}

Prema ZKP-u, koji je stupio na snagu 2008., a takvo je zakonsko rješenje bilo i u ZKP/97, ${ }^{34}$ imovinskopravni zahtjev raspravljao se na prijedlog ovlaštenih osoba. To znači da su prijedlog za ostvarenje imovinskopravnoga zahtjeva osim oštećenika, mogle podnijeti i druge osobe koje su prema pravilima parničnog postupka ovlaštene na podnošenje tužbe. Dakle, to su mogle biti i osobe na koje je prešla tražbina oštećenika koja je nastala počinjenjem kaznenog djela.

Izmjenama i dopunama $\mathrm{ZKP} / 08$ iz 2017. to je izmijenjeno tako da se imovinskopravni zahtjev raspravlja samo na zahtjev oštećenika (čl. 154. st. 1.ZKP/08). ZKP/08 definira oštećenika kao žrtvu i pravnu osobu na čiju je štetu kazneno djelo počinjeno i koji se prijave kao oštećenici. Žrtva kaznenog djela je osoba koja zbog počinjenja kaznenog djela trpi fizičke i duševne posljedice, imovinsku štetu ili bitnu povredu temeljnih prava i sloboda te je stoga uži pojam od oštećenika (čl. 202. st. 2. t. 11. i 12. ZKP/08). To je sukladno definiciji koja je sadržana u Direktivi 2012/29/ EU Europskog parlamenta i Vijeća od 25. listopada 2012. o uspostavi minimalnih standarda za prava, potporu i zaštitu žrtava kaznenih djela te o zamjeni Okvirne odluke Vijeća 2001/220/PUP, a prema kojoj se u smislu čl. 2. žrtvom definira fizička osoba koja je pretrpjela štetu, uključujući tjelesnu, umnu ili emocionalnu štetu ili ekonomski gubitak koji je izravno uzrokovan kaznenim djelom i članovi obitelji osobe čija je smrt izravno uzrokovana kaznenim djelom i koji su pretrpjeli štetu kao posljedicu smrti te osobe. ${ }^{35}$ Čl. 16. navedene Direktive određena je obveza države članice osigurati da žrtve u okviru kaznenog postupka imaju pravo na odluku o naknadi štete od_strane počinitelja u razumnom roku, osim ako je nacionalnim pravom predviđeno da se takva odluka mora donijeti u drugom postupku.

Time što je žrtva odlučila sudjelovati u kaznenom postupku, postala je oštećenik. Kad prijedlog za ostvarenje imovinskopravnog zahtjeva u kaznenom postupku podnosi žrtva kaznenog djela, mora navesti u prijedlogu je li ostvarila novčanu naknadu iz sredstava državnog proračuna ili podnijela zahtjev prema čl. 43. st. 3. ZKP/08. ${ }^{36}$

Iz navedenoga proizlazi da je oštećenik ponajprije osoba čije je neko osobno ili imovinsko pravo kaznenim djelom povrijeđeno ili ugroženo. On može biti fizička ili pravna osoba te mora imati stranačku i parničnu sposobnost. Oštećenik u

34 Zakon o kaznenom postupku, Narodne novine, br. 110/97., 27/98., 112/99., 58/02., 143/02., 62/03., 115/06., (dalje: ZKP/97).

35 Prema presudi Suda Europske unije broj C-603/19 od 01. listopada 2020., Direktiva 2012/29/ EU od 25. listopada 2012. se ne primjenjuje ni na pravne osobe ni na državu iako im nacionalno pravo dodjeljuje svojstvo oštećenika u okviru kaznenog postupka.

36 Odredbom čl. 43. st. 3. ZKP/08 propisano je da žrtva kaznenog djela nasilja počinjenog $\mathrm{s}$ namjerom ima pravo na novčanu naknadu iz sredstava državnog proračuna u skladu $\mathrm{s}$ posebnim zakonom (riječ je o Zakonu o novčanoj naknadi žrtvama kaznenih djela, Narodne novine, br. 80/08.). Ako je žrtva prethodno ostvarila imovinskopravni zahtjev pri odmjeravanju novčane naknade uzet će se u obzir njegova visina. Tako će postupiti i sud pri dosuđivanju imovinskopravnog zahtjeva ako je žrtva prethodno ostvarila novčanu naknadu iz sredstava državnog proračuna. 
kaznenom postupku nema uvijek položaj stranke, ali neovisno o tome može podnijeti imovinskopravni zahtjev i kad nije stranka u postupku. Naime, stranke u kaznenom postupku su tužitelji i okrivljenik (čl. 202. st. 2. t. 13. ZKP/08), ali ne i oštećenik. To znači da oštećenik bez obzira na to što je podnio imovinskopravni zahtjev ne mora imati položaj stranke u kaznenom postupku, već samo kada je u položaju oštećenika kao tužitelja. ${ }^{37}$ Položaj oštećenika u kaznenom postupku znatno bi bio poboljšan kada bi mu se priznao položaj stranke u postupku jer bi time mogao ostvarivati i neka prava koja kao oštećenik bez položaja stranke nema, što osobito dolazi do izražaja kod prava na podnošenje pravnih lijekova protiv odluka suda. ${ }^{38}$ Ako je riječ o oštećeniku koji je podnio prijedlog za ostvarivanje imovinskopravnog zahtjeva on udovoljava svim zahtjevima koji se u teoriji građanskog procesnog prava zahtijevaju za stjecanje položaja stranke kao procesnog subjekta. Tako se stranka (na tužiteljskoj strani) definira kao osoba koja u svoje ime, odnosno u čije se ime zahtijeva od suda pružanje pravne zaštite određenog sadržaja pravima za koja se tvrdi da su ugrožena ili povrijeđena. ${ }^{39} \mathrm{U}$ parničnom postupku položaj stranke stječe se podnošenjem tužbe sudu. Stoga bi analogno navedenom, oštećenik taj položaj u kaznenom postupku trebao stjecati podnošenjem imovinskopravnog zahtjeva.

Međutim, osim neposredno oštećenog tijekom vođenja kaznenog postupka se zbog različitih okolnosti mogu pojaviti i njegovi univerzalni ili singularni sukcesori.

Univerzalni sukcesori su nasljednici fizičke osobe, odnosno pravni slijednici pravne osobe (kod prestanka ili pripajanja pravne osobe). ${ }^{40} \mathrm{Na}$ univerzalne sukcesore prelazi cjelokupnost prenosivih prava i obveza njihova prednika. Ako je riječ o zahtjevu za naknadu štete pravilo je da je imovinska šteta nasljediva. No, tražbina neimovinske štete prelazi na nasljednika samo ako je oštećenik podnio pisani zahtjev ili tužbu (čl. 1105. ZOO). ${ }^{41}$ Kod univerzalne sukcesije zbog smrti fizičke osobe sukcesija se u pravilu dokazuje rješenjem o nasljeđivanju, iako ostavina umrle osobe prelazi na njegove nasljednike već trenutkom smrti ostavitelja. ${ }^{42}$ Kod prestanka ili

37 Prema čl. 202. st. 2. t. 14. ZKP/08 tužitelj je državni odvjetnik, oštećenik kao tužitelj i privatni tužitelj.

38 Tendencija sve šireg priznavanja prava oštećenicima proizlazi i iz prakse Ustavnog suda Republike Hrvatske prema kojoj se oštećenicima priznaje pravo na podnošenje ustavne tužbe zbog duljine kaznenog postupka iako nisu postavili imovinskopravni zahtjev u kaznenom postupku čime je izmijenjena dotadašnja suprotna praksa. Tako je u Odluci br. U-IIIVs-3511/2006. od 22. listopada 2008. između ostalog navedeno kako pravo supsidijarnog kaznenog progona, doduše, nije istovjetno s pravom isticanja imovinskopravnog zahtjeva, odnosno naknade štete od okrivljenika. No, kada zakon oštećenika ovlašćuje da nastupa kao kazneni progonitelj umjesto državnog odvjetnika onda on u sadržaj te ovlasti ne uključuje samo zaštitu javnog interesa na kažnjavanje počinitelja kaznenog djela nego i zaštitu pojedinačnog interesa oštećenika kao žrtve kaznenog djela da počinitelj bude pravedno i svrhovito kažnjen sukladno svrsi kažnjavanja propisanoj Kaznenim zakonom (čl. 50.).

39 Triva i Dika, Građansko parnično procesno pravo, 231.

40 Triva i Dika, Građansko parnično procesno pravo, 222: Univerzalna građanskopravna sukcesija - naravno samo u pogledu prenosivih prava - dovodi ex lege do procesnopravne sukcesije (nasljeđivanje fizičke osobe ili pripajanje pravne osobe).

41 Zakon o obveznim odnosima, Narodne novine, br. 35/05., 41/08., 125/11.,78/15., 29/18. (dalje: ZOO).

42 Čl. 129. Zakona o nasljeđivanju, Narodne novine, br. 48/03., 163/03., 35/05., 127/13., 33/15., 
pripajanja pravne osobe sukcesija se dokazuje uvidom u registar u koji je upisana pravna osoba.

Do singularne sukcesije na strani vjerovnika u obveznom pravu dolazi ustupanjem tražbine, ispunjenjem sa subrogacijom i ustupanjem ugovora. Ustup tražbine naziva se još i cesija, a znači da vjerovnik može ugovorom sklopljenim s trećim prenijeti na ovoga svoju tražbinu, osim one čiji je prijenos zabranjen zakonom ili je strogo osobne naravi, ili koja se po svojoj naravi protivi prenošenju na drugoga (čl. 80.-89. ZOO). Ispunjenje sa subrogacijom može biti ugovorno (čl. 90. ZOO) ili zakonsko (čl. 91. ZOO). U slučaju ispunjenja tuđe obveze svaki ispunitelj može ugovoriti s vjerovnikom prije ispunjenja ili pri ispunjenju, da ispunjena tražbina prijeđe na njega sa svima ili samo s nekim sporednim pravima, a subrogacija ispunitelja u prava vjerovnika nastaje $u$ trenutku ispunjenja. Zakonsko ispunjenje sa subrogacijom naziva se još i nužna cesija do koje dolazi kad dužnikovu obvezu vjerovniku ispuni osoba koja ima neki pravni interes u tome, pa na nju prelazi po samom zakonu u trenutku ispunjenja vjerovnikova tražbina sa svim sporednim pravima. Ispunitelj na kojeg je prešla tražbina ne može zahtijevati od dužnika više nego što je isplatio vjerovniku.

Sve do 2017. nije bilo zapreke za podnošenje imovinskopravnog zahtjeva univerzalnih ili singularnih sukcesora oštećenika. Kada su bili u pitanju singularni sukcesori najčešće je bila riječ o, tzv. regresnom oštećeniku, odnosno osiguratelju koji je naknadio štetu svom osiguraniku koji je neposredno oštećen počinjenjem kaznenog djela. Mogući prigovori da takva osoba nije oštećenik upravo su se otklanjali pozivom na tada važeće zakonsko uređenje prema kojem je prijedlog za ostvarivanje imovinskopravnog zahtjeva u kaznenom postupku mogla podnijeti osoba koja je ovlaštena da takav zahtjev ostvaruje u parnici, a to je svakako osiguratelj koji je naknadio štetu svom osiguraniku. ${ }^{43}$ Izmjenama ZKP-a iz 2017. to se pravo izrijekom ograničava samo na oštećenika, a prema zakonskoj definiciji oštećenika, sukcesori (osobito singularni) to nisu. To ukazuje da je došlo do sužavanja kruga osoba ovlaštenih na podnošenje imovinskopravnog zahtjeva.

Mišljenje je autora kako ipak nema osnove uskratiti to pravo univerzalnim sukcesorima oštećenika. Krug osoba kojima se u kaznenom postupku omogućava podnošenje prijedloga za progon ili tužbe, odnosno nastavljanja postupka u slučaju smrti žrtve još je i širi od kruga zakonskih nasljednika. ${ }^{44}$ To pravo ima i pravni sljednik pravne osobe na čiju je štetu kazneno djelo počinjeno u slučaju prestanka te osobe. Analogno navedenom, univerzalni sukcesori oštećenika (i pravni sljednici pravne osobe) trebali bi biti ovlašteni podnijeti i prijedlog za ostvarivanje imovinskopravnog zahtjeva bez obzira na to što je do smrti oštećenika došlo prije nego što je podnio taj prijedlog.

Ako dođe do prijenosa imovinskopravnog zahtjeva po pravilima imovinskog prava na drugu osobu nakon što je već podnesen prijedlog u kaznenom postupku,

14/19. (dalje: ZN).

43 U tom se smislu navodi i u odluci Vrhovnog suda Republike Hrvatske, Kž 262/16 od 7. lipnja 2016.

44 Prema čl. 48. ZKP/08 to su njihov bračni i izvanbračni drug, životni partner ili neformalni životni partner te potomak. Ako njih nema, onda je to predak, brat, sestra te osoba koju je žrtva odnosno oštećenik na temelju zakona bio dužan uzdržavati. 
ali prije završetka dokaznog postupka, ta će se osoba pozvati da se očituje ostaje li pri prijedlogu. Smatrat će se da je uredno pozvani koji se ne odazove, odustao od stavljenog prijedloga (čl. 156. st. 2. ZKP/08). Iz navedenog slijedi da bi i univerzalni i singularni sukcesori oštećenika, ako do sukcesije dođe nakon podnošenja prijedloga za ostvarenje imovinskopravnog zahtjeva, mogli stupiti u kazneni postupak umjesto ranijeg oštećenika. Stoga bi trebalo preispitati smisao ograničavanja tih osoba $u$ ovlaštenju na inicijalno podnošenje tog prijedloga.

\subsection{Pasivna legitimacija}

Zakon izričito ne navodi protiv koga se ističe imovinskopravni zahtjev, međutim, logično je da se ističe prema okrivljeniku.

Prema ZKP/97 postojala je mogućnost da se, ako se imovinskopravni zahtjev odnosio na povrat stvari, a sud utvrdi da stvar pripada oštećeniku i da se nalazi kod osobe ili tijela kod kojeg se stvar nalazi, odredi u presudi da se stvar preda oštećeniku (čl. 133. ZKP/97). Navedena je odredba bila kritizirana i to zbog toga što je treća osoba mogla presudom biti obvezana na činidbu, a da protiv nje imovinskopravni zahtjev nije bio niti postavljen, niti je bila stranka u postupku s mogućnosti raspravljanja. ${ }^{45}$ $\mathrm{ZKP} / 08$ takvu odredbu više ne sadrži što je na prvi pogled pozitivna izmjena $s$ obzirom na to da uistinu nije bilo jasno kako bi se osigurao procesni položaj treće osobe $\mathrm{u}$ kaznenom postupku s obzirom na to da ZKP/97 nije imao, a ni ZKP/08 nema, o tome odgovarajuće odredbe. Konkretno, nije riječ bi li sudjelovanje treće osobe opteretilo kazneni postupak ili ne, već o tome da se trećoj osobi, kojoj se u postupku nalaže ispunjenje neke obveze, moraju osigurati sva procesna prava, a koja ona prema važećem zakonskom uređenju nema u kaznenom postupku. U protivnom bi se kršila njezina Ustavom ${ }^{46}$ zajamčena prava i to osobito pravo na jednaku pravnu zaštitu i pravo na pravično suđenje (čl. 26. i 29. Ustava). ${ }^{47}$ Kako bi se osigurao odgovarajući procesni položaj treće osobe u kaznenom postupku, ona bi morala imati sva prava koja bi kao tuženik imala u parničnom postupku. ${ }^{48}$ Ima li se u vidu mogućnost da se stvari

$45 \mathrm{O}$ tome vidi više Kunštek, Imovinskopravni zahtjevi, 178.

46 Ustav Republike Hrvatske, Narodne novine, br. 56/90., 135/97., 08/98., 113/00., 124/00., 124/00., 28/01., 41/01., 55/01., 76/10., 85/10., 05/14. (dalje: Ustav).

47 Načelo jednakosti sredstava, u smislu pravične ravnoteže među strankama (fair balance) čini jedan od bitnih konstitutivnih elemenata prava na pravično suđenje. S tim u vezi, to načelo nužno obuhvaća razumnu mogućnost stranaka da izlože činjenice i podupru ih svojim dokazima na način da niti jednu od stranaka ne stavljaju u bitno lošiji položaj u odnosu na suprotnu stranku. Iz prava na jednakost oružja izvode se i pojedina prava u odnosu na izbor i izvođenje dokaza. - Ustavni sud Republike Hrvatske u odluci br. U-III-4581/2013. od 20. lipnja 2017.

48 Radi usporedbe, ZKP/08 svojim je izmjenama iz 2017. znatno novelirao institut oduzimanja imovinske koristi i određivanje privremenih mjera radi njezina osiguranja implementirajući i Direktivu 2014/42/EU Europskog parlamenta i Vijeća od 03. travnja 2014. o zamrzavanju i oduzimanju predmeta i imovinske koristi ostvarene kaznenim djelima u Europskoj uniji. Direktiva u svojim uvodnim odredbama ukazuje da je sve prisutnija praksa osumnjičenika ili optuženika da prenesu imovinu poznatoj trećoj strani u cilju izbjegavanja oduzimanja. Kako prethodno pravni okvir Unije nije obuhvaćao obvezujuća pravila o oduzimanju imovine prenesene trećim stranama sve je potrebnije dopustiti oduzimanje imovine prenesene na treću stranu ili imovine koju je treća strana stekla. Stoga je Direktivom propisano da države članice 
otuđene počinjenjem kaznenog djela ${ }^{49}$ ne moraju nalaziti kod okrivljenika nego kod neke treće osobe, za oštećenika i učinkovito ostvarenje njegovih prava bilo bi znatno povoljnije kada bi mogao svoj imovinskopravni zahtjev postaviti i protiv treće osobe. Međutim, pri tome je potrebno propisati (kao što je to, npr. učinjeno kod oduzimanja imovinske koristi u čl. 558. ZKP/08) koja bi sve procesna prava pripadala toj trećoj osobi. Zakonsko uređenje trebalo bi ići u smjeru propisivanja obveze pozivanja treće osobe na sva ročišta, omogućavanja predlaganja dokaza i aktivnog sudjelovanja u njihovu izvođenju te obveze dostavljanja svih odluka koje utječu na njezina prava uz utvrđivanje prava na podnošenje pravnih lijekova. ${ }^{50}$

Kod zahtjeva za naknadu štete, oštećeniku se priznaje pravni interes da traži naknadu izravno od odgovorne osobe koja mu je prouzročila štetu, čak i ako ona nije počinjenjem kaznenog djela ostvarila imovinsku korist za sebe. ${ }^{51}$ Sama činjenica da se korist iz kaznenog djela nalazi kod treće osobe i da je počinitelj postupao kako bi upravo njoj, a ne sebi osobno, takvu korist pribavio, neće dovesti do isključenja odgovornosti počinitelja za štetu koju je takvim postupanjem prouzročio oštećeniku. Već to što je riječ o počinitelju kaznenog djela uspostavlja izvanugovorni odnos prema oštećeniku kojim je počinitelj kaznenog djela obvezan nadoknaditi kaznenim djelom

poduzimaju potrebne mjere kako bi omogućile oduzimanje imovinske koristi ili druge imovine čija vrijednost odgovara imovinskoj koristi koju je osumnjičenik odnosno optuženik neizravno ili izravno prenio trećim stranama ili su je treće strane stekle od osumnjičenika odnosno optuženika, barem ako su te treće strane znale ili su morale znati da je namjera prijenosa ili stjecanja bila izbjegavanje oduzimanja.

Izmjenama i dopunama ZKP-a iz 2017. u odredbama čl. 557-563. predviđeno je i da se privremene mjere radi osiguranja oduzimanja imovinske koristi ostvarene protupravnom radnjom i samo oduzimanje imovinske koristi može odrediti i u odnosu na drugu osobu na koju je prenesena imovinska korist. Međutim, prava te druge osobe ili treće osobe koja tvrdi da vezano za imovinu koju je potrebno osigurati ili oduzeti ima pravo koje sprječava primjenu odredbi o određivanju privremene mjere i oduzimanja imovinske koristi, osigurana su mogućnošću sudjelovanja te osobe u postupku, dostavljajući joj odluku koja se tiče imovinske koristi i davanjem ovlaštenja na izjavljivanje pravnih lijekova protiv odluka suda (čl. 557a, čl. 558. i čl. 464. st. 5. ZKP/08).

49 Osim kod zahtjeva za povrat stvari mogućnost podnošenja imovinskopravnog zahtjeva protiv treće osobe u kaznenom postupku mogla bi se pozitivno odraziti i na neke zahtjeve za naknadu štete (npr. kod građanskopravne odgovornosti osiguratelja ili poslodavca), ali i kod zahtjeva za poništenje ili utvrđenje ništetnosti pravnih poslova nastalih počinjenjem kaznenog djela u kojima okrivljenik i oštećenik nisu jedine ugovorne strane.

50 U kontekstu zaštite prava treće osobe ESLJP je u presudi Brkljačić protiv Republike Hrvatske od 23. kolovoza 2016. (\$37) naveo da bi kao opće načelo, osobama čija se imovina oduzima trebalo formalno dati status stranaka u postupku u kojem je oduzimanje naloženo. To posebno znači da pravo na pristup sudu može biti zadovoljeno omogućavanjem trećoj osobi na čija se vlasnička prava utječe u kaznenom postupku učinkovitog razmatranja njezinih pritužbi u kontekstu tog postupka. Obraćanje građanskom ili upravnom sudu predstavljalo bi daljnje pravne putove koje podnositelj zahtjeva može iskoristiti kako bi uživao svoje pravo na pristup sudu.

51 Ines Grubišić, ,Imovinskopravni zahtjev prema okrivljeniku odgovornoj osobi kada je kaznenim djelom pribavio imovinsku korist za pravnu osobu“, Zbornik Pravnog fakulteta Sveučilišta u Rijeci, br. 2, 2014, 753. 
prouzročenu štetu. ${ }^{52}$

Kada je više okrivljenika u kaznenom postupku oni su solidarno odgovorni i ta solidarnost kod isplate dosuđenog imovinskopravnog zahtjeva mora biti naznačena u odluci (naravno, ako je oštećenik prijedlog podnio u odnosu na sve okrivljenike). Solidarna obveza definira se kao takav obvezni odnos u kojemu je svaki od više suvjerovnika ovlašten zahtijevati ispunjenje cijele činidbe od bilo kojeg dužnika. Pritom je svaki od više sudužnika obvezan ispuniti cijelu činidbu, premda je ona djeljiva. Ako je činidba jednom ispunjena, namireni su svi vjerovnici i oslobođeni svi dužnici. ${ }^{53}$ Prema ZOO-u za štetu koju je prouzročilo više osoba zajedno, svi sudionici odgovaraju solidarno. Isto tako poticatelj i pomagač te onaj koji je pomagao da se odgovorne osobe ne otkriju odgovaraju solidarno s njima (čl. 1107 st. 1. i 2. ZOO). To znači da i pomagač u počinjenju kaznenog djela solidarno odgovara za naknadu štete koja je počinjena izvršenjem kaznenog djela. Stoga bi trebalo presuditi da su oba okrivljenika obvezni solidarno naknaditi postavljeni imovinskopravni zahtjev od strane oštećenika.

S obzirom na to da o dispoziciji oštećenika ovisi hoće li imovinskopravni zahtjev biti podnesen ili ne, treba uzeti u obzir da o njegovoj dispoziciji ovisi i prema kojem će od više okrivljenika, ako se kazneni postupak vodi protiv više okrivljenika, podnijeti imovinsko pravni zahtjev. Dakle, oštećenik nije dužan istaknuti imovinskopravni zahtjev prema svim okrivljenicima i takvu njegovu procesnu dispoziciju treba uvažiti. ${ }^{54}$

\section{PRETPOSTAVKE ZA ODLUČIVANJE}

Iz već citirane odredbe čl. 153. ZKP/08 jasno proizlaze osnovne pretpostavke koje se moraju ispuniti da bi sud odlučivao o imovinskopravnom zahtjevu u kaznenom postupku, a to su: 1. da je oštećenik podnio prijedlog - pozitivna pretpostavka i 2. da se raspravljanjem o imovinskopravnom zahtjevu znatno ne odugovlači kazneni postupak - negativna pretpostavka.

\subsection{Pozitivna pretpostavka}

Sud će u kaznenom postupku raspravljati o imovinskopravnom zahtjevu samo ako je oštećenik takav zahtjev podnio. To znači da raspravljanje ovisi o dispoziciji oštećenika i o njemu sud nije ovlašten ni dužan odlučivati po službenoj dužnosti. ${ }^{55}$ O dispoziciji oštećenika ovisi i okončanje vođenja tog postupka unutar kaznenog postupka. Tako oštećenik može do završetka dokaznog postupka odustati od prijedloga za ostvarivanje imovinskopravnog zahtjeva u kaznenom postupku i ostvarivati ga $\mathrm{u}$ parnici (čl. 156. st. 1. ZKP/08). Međutim, ako odustane od prijedloga, više ga ne može ponovno staviti u kaznenom postupku i tada mu jedino preostaje mogućnost

52 Tako i Vrhovni sud Republike Hrvatske u odluci Kzz 42/10 od 6. listopada 2010.

53 Ivica Crnić, Odštetno pravo, 2. bitno izmijenjeno i dopunjeno izd, (Zagreb: Zgombić i partneri, 2008.), 158.

54 V. Kunštek, Imovinskopravni zahtjevi, 172.

55 U tom smislu i Vrhovni sud Republike Hrvatske u odluci broj Kž 483/2020 od 21. rujna 2020. 
vođenja parnice. Sve je to odraz načela dispozitivnosti56 ${ }^{50 j e ~ u ~ p a r n i c ̌ n o m ~ p o s t u p k u ~}$ omogućava strankama da slobodno raspolažu zahtjevima koje su stavile tijekom postupka, a sud odlučuje samo u granicama stavljenih zahtjeva (čl. 2. i 3. ZPP).

U prijedlogu je oštećenik obvezan određeno naznačiti svoj zahtjev i podnijeti dokaze (čl. 155. st. 3. ZKP/08). Određeno naznačiti zahtjev znači da zahtjev mora biti određen u pogledu glavne stvari i sporednih traženja. ${ }^{57}$ Neodređeni navodi oštećenika o tome što im je otuđeno ili da im ukradeni novac i predmeti nisu vraćeni ne mogu se smatrati postavljanjem imovinskopravnog zahtjeva. Međutim, imovinskopravni zahtjev može biti određen i na način da ima dostatno podataka s pomoću kojih se može odrediti. ${ }^{58}$ Predloženi dokazi moraju biti takvi da se na temelju njih može pouzdano utvrditi osnovanost i visina imovinskopravnog zahtjeva. Sve je to u skladu s pravilom da sud nije ovlašten tužitelju dosuditi ni više od onoga što je tražio ni nešto drugo, što nije tražio, čak i kad ga rezultati raspravljanja dovedu do zaključka da tužitelju pripada više nego što je tražio ili da mu doduše ne pripada ono što je tražio, ali da mu pripada nešto drugo. ${ }^{59}$

S obzirom na to da prijedlog oštećenika zamjenjuje tužbu, trebao bi imati sve elemente koje mora imati i tužba počevši od već navedenog određenog zahtjeva u pogledu glavne stvari i sporednih traženja te dokaza kojima se utvrđuju činjenice na kojima se temelji zahtjev, ali i druge podatke koje mora imati svaki podnesak (čl. 186. st. 1. ZPP). ${ }^{60}$ Ako je oštećenik podnio prijedlog za ostvarivanje imovinskopravnog zahtjeva koji ne sadrži sve što je potrebno da bi se po njemu moglo postupiti sud može odgovarajuće primijeniti odredbu čl. 78. ZKP/08 i pozvati oštećenika da podnesak ispravi, odnosno dopuni, a ako on to ne učini u određenom roku, podnesak, dakle prijedlog oštećenika, odbaciti.

\subsection{Negativna pretpostavka}

O imovinskopravnom zahtjevu sud u kaznenom postupku neće raspravljati ako bi to dovelo do znatnog odugovlačenja postupka već će u tom slučaju oštećenika uputiti na parnicu. Međutim, zakon pobliže ne određuje što to znači, odnosno kada se može smatrati da bi raspravljanje o imovinskopravnom zahtjevu dovelo do toga. Tako neprecizan pojam omogućuje njegovo različito tumačenje pa i mogućnost da sud i bez opravdanih razloga oštećenika uputi u parnicu. Iz opisanog se može izvesti zaključak da sud ima diskrecijsko pravo odlučiti hoće li se o imovinskopravnom zahtjevu uopće odlučivati unutar kaznenog postupka. ${ }^{61}$ Takvo postupanje se, u nedostatku preciznoga

56 Triva i Dika navode kako je trebalo uvažiti da proces nije sam sebi svrha, već instrument za zaštitu građanskih prava u skladu s načelima pravnoga poretka, Triva i Dika, Građansko parnično procesno pravo, 127.

57 Tako i u odluci Županijskog suda u Varaždinu, Gž 372/2007 od 13. lipnja 2007.

58 U odluci Vrhovnog suda Republike Hrvatske, Kž 434/11 od 21. prosinca 2011. kao dovoljno određen zahtjev je ocijenjen zahtjev kojeg je oštećenik postavio u iznosu za koji je oštećen, a prema podacima banke.

59 Triva i Dika, Građansko parnično procesno pravo, 130.

60 Više o sadržaju tužbe vidi u Mihajlo Dika, Građansko parnično pravo, Tužba, VI knjiga (Zagreb: Narodne novine, 2009.), 68.

61 V. Kunštek, Actio civilis u kaznenom postupku, 211. 
zakonskog uređenja, može spriječiti samo ako postoji učinkovita mogućnost preispitivanja odluke suda, a pravni interes za to ima upravo oštećenik koji je upućen u parnicu i o čijem imovinskopravnom zahtjevu sud nije odlučio ili nije odlučio u cijelosti. Davanjem oštećeniku mogućnosti izjavljivanja pravnih lijekova protiv odluke suda jača se njegov procesni položaj u kaznenom postupku. Stoga je za ocjenu položaja oštećenika potrebno utvrditi koje mogućnosti ima oštećenik koji smatra da je sud mogao odlučiti o njegovu imovinskopravnom zahtjevu umjesto što ga je uputio na parnicu.

Prema ZKP/97 oštećenik nije imao na raspolaganju nikakva pravna sredstva protiv odluke suda o imovinskopravnom zahtjevu. ${ }^{62}$ Takvo zakonsko uređenje bilo je predmet čestih kritika s prijedlozima da bi mogućnost donošenja odluke u pravcu neraspravljanja o postavljenom zahtjevu oštećenika trebalo, ili onemogućiti, ili barem postaviti daleko restriktivnije. ${ }^{63}$

Prema ZKP/08 oštećenik može pobijati presudu zbog odluke suda o njegovim troškovima kaznenog postupka i odluke o imovinskopravnom zahtjevu. ${ }^{64}$ Ako je državni odvjetnik preuzeo progon od oštećenika kao tužitelja, oštećenik može podnijeti žalbu zbog svih osnova zbog kojih se presuda može pobijati (čl. 464. st. 4. ZKP/08). Odluka o imovinskopravnom zahtjevu može se pobijati kad je sud o tim pitanjima donio odluku suprotno zakonskim propisima (čl. 471. st. 3. ZKP/08). Neki autori, međutim, smatraju kako odluka suda da ne raspravlja o imovinskopravnom zahtjevu, odnosno odluka o upućivanju u parnicu nije odluka o imovinskopravnom zahtjevu, već o odbijanju postupanja. ${ }^{65}$ Ipak, mjerodavna praksa sudova ukazuje da je žalba oštećenika protiv odluke, kojom ga sud u kaznenom postupku upućuje na parnicu, dopuštena. ${ }^{66}$ To upućuje na zaključak da se, barem u praksi, ako ne i u teoriji, odluka o upućivanju u parnicu ipak smatra odlukom o imovinskopravnom zahtjevu što je za oštećenika svakako povoljnije i poboljšava njegov pravni položaj u kaznenom postupku.

Sud je o imovinskopravnom zahtjevu dužan donijeti neku od odluka koje se navode u čl. 158. st. 2. ZKP/08, dakle, oštećeniku dosuditi imovinskopravni zahtjev u cijelosti ili djelomično, a za ostatak ga uputiti u parnicu ili ga s imovinskopravnim zahtjevom u cijelosti uputiti u parnicu. Navedena je odredba kogentna norma i sud

62 Prema ZKP/97 oštećenik nije mogao pobijati presudu zbog odluke o imovinskopravnom zahtjevu (čl. 363. st. 4 ZKP/97) već samo zbog odluke o troškovima kaznenog postupka.

63 Kunštek navodi kako je pojam znatno odugovlačenje dosta neprecizan i podložan različitim interpretacijama, slijedom čega omogućava sudu da ne odlučuje kad god smatra, opravdano ili ne, da će zbog toga doći do odugovlačenja postupka. Kunštek, Actio civilis u kaznenom postupku, 211.

64 Pravomoćnu presudu kojom je odlučeno o imovinskopravnom zahtjevu sud u kaznenom postupku može izmijeniti samo u povodu izvanrednog pravnog lijeka (čl. 159 st. 1. ZKP/08). Oštećenik ne može izjaviti niti jedan izvanredni pravni lijek protiv pravomoćne presude pa ta mogućnost za njega ne postoji u kaznenom postupku.

65 Kunštek, Actio civilis u kaznenom postupku, 211.

66 Uočeno je da su drugostupanjski sudovi razmatrali i odlučivali o žalbi oštećenika podnesenoj protiv odluke kojom ga prvostupanjski sud upućuje u parnicu i to, primjerice u predmetima broj Županijski sud u Zagrebu, Kžzd-201/17, Vrhovni sud Republike Hrvatske, Kž 483/20 i Kž 147/17, Županijski sud u Varaždinu, Kžmp-15/19 i dr., https://sudskapraksa.csp.vsrh.hr/. 
nema diskrecijsko pravo prosuđivati hoće li odlučivati ili ne o imovinskopravnom zahtjevu. ${ }^{67}$ Ako sud uputi oštećenika s imovinskopravnim zahtjevom na parnicu, a pritom uopće ne obrazloži takvu svoju odluku, time izreku presude u dijelu odluke za kazneno djelo čini proturječnu samoj sebi. ${ }^{68} \mathrm{Zbog}$ navedene povrede kaznenog postupka tužitelj je ovlašten podnijeti žalbu protiv presude, a glavni državni odvjetnik i zahtjev za zaštitu zakonitosti. Oštećenik, koji nije ujedno i tužitelj u kaznenom postupku, nema tu mogućnost, pa prema važećem zakonodavnom uređenju nema učinkovitu zaštitu u situacijama kada, npr. sud uopće ne odluči o njegovu imovinskopravnom zahtjevu jer ovisi o odluci ovlaštenog tužitelja hoće li zbog tog razloga izjaviti žalbu protiv presude ili ne.

Ako je iznos imovinskopravnog zahtjeva nedvojbeno utvrđen, sud mora odučiti o njemu pa pravo da ne odlučuje o imovinskopravnom zahtjevu postoji tek kada podatci u kaznenom postupku ne daju pouzdanu osnovu ni za potpuno ni za djelomično presuđenje. ${ }^{69}$ Vrhovni sud Republike Hrvatske jasno ukazuje kako je pogrešno stajalište da odluka o dosudi imovinskopravnog zahtjeva kao akcesorna odluka može, ali i ne mora biti donesena u prvostupanjskom kaznenom postupku onda kada je iznos štete precizno naznačen u izreci presude. Kada sud utvrdi da je za oštećenika počinjenjem kaznenog djela nastupila šteta u određenom iznosu, tada su ujedno utvrđene sve zakonske pretpostavke da se prihvati postavljeni imovinskopravni zahtjev. ${ }^{70}$

Sud najčešće nedvojbeno utvrđuje visinu štete koju je pretrpio oštećenik u situacijama kada je ostvarena korist ili počinjena šteta konstitutivni ili kvalifikatorni element kaznenog djela. Tako je utvrđivanje visine štete, s obzirom na to da je bitno utvrditi je li riječ o znatnoj šteti ili ne, odlučno kod kaznenih djela krađe, teške krađe, razbojništva, utaje, oštećenja tuđe stvari, prijevare, nedozvoljene igre na sreću, zlouporabe povjerenja, lihvarskog ugovora, iznude, zlouporabe povjerenja u gospodarskom poslovanju, prijevare u gospodarskom poslovanju, prouzročenju stečaja, zlouporabe u postupku javne nabave, zlouporabe povlaštenih informacija, zlouporabi položaja i ovlasti i dr. ${ }^{71}$ I u situacijama kada utvrđivanje visine pretrpljene štete nije konstitutivno obilježje kaznenog djela treba izbjegavati stav, prema kojem bi već okolnost da se treba odrediti i provesti neki dokaz radi utvrđivanja visine imovinskopravnog zahtjeva bio razlog za upućivanje u parnicu i otklanjanje odlučivanja o imovinskopravnom zahtjevu u kaznenom postupku. Pojam ,znatno odugovlačenje kaznenog postupka“" trebalo bi tumačiti restriktivno, a sud bi se svojim ovlaštenjem trebao koristiti samo ako bi uistinu bila riječ o odugovlačenju u znatnoj mjeri, a ne već samo zbog toga što bi odlučivanje zahtijevalo izvođenje dodatnih

67 Navedeni stav nedvojbeno proizlazi i iz odluke Vrhovnog suda Republike Hrvatske, Kzz 1/07 od 24. travnja 2007. koja je donesena u primjeni ZKP/97 i to čl. 132. st. 2. koja sadržajno odgovora odredbi čl. 158. st. 2. ZKP/08.

68 Tako Vrhovni sud Republike Hrvatske u odluci Kž-123/1998 od 21. veljače 2001.

69 U tom smislu i Vrhovni sud Republike Hrvatske u odluci Kzz-13/03 od 9. listopada 2003.

70 Detaljnije Vrhovni sud Republike Hrvatske u odluci Kzz 42/10 od 6. listopada 2010.

71 O pojedinim kaznenim djelima vidi više u Kaznenom zakonu Republike Hrvatske, Narodne novine, br. 125/11., 144/12., 56/15., 61/15., 101/17., 118/18., 126/19. (dalje: KZ). 
dokaza koji se inače ne bi izvodili. ${ }^{72}$

Sud u kaznenom postupku mora izvoditi dokaze radi utvrđivanja kaznene odgovornosti okrivljenika. Dokazivanje je izvođenje onih procesnih radnji kojima se s pomoću dokaza utvrđuju činjenice kako bi se pravo primijenilo samo na pouzdano dokazane činjenice..$^{73}$ Iako imovinskopravni zahtjev nije predmet optužbe u kaznenopravnom smislu treba imati u vidu da je sud dužan tijekom kaznenog postupka prikupljati dokaze i istraživati okolnosti koje su važne za utvrđivanje imovinske koristi (čl. 557. st. 3. ZKP/08). Imovinska korist često korespondira imovinskopravnom zahtjevu pa će pretpostavljeno te aktivnosti koristiti i pri utvrđivanju visine imovinskopravnog zahtjeva koji ima prednost u odnosu na oduzimanje imovinske koristi. Opseg dokazivanja treba biti takav da utvrđene činjenice iz kaznenog predmeta daju pouzdanu osnovu za usvajanje imovinskopravnog zahtjeva oštećenika. Dakle, da je izvedeno dostatno dokaza na temelju kojih bi sud mogao to utvrditi na vjerodostojan način.

Gledajući općenito, mogao bi se izvesti zaključak da su prava oštećenika dovoljno zaštićena već time što uz mogućnost isticanja imovinskopravnog zahtjeva u kaznenom postupku ima i mogućnost ostvarivanja svog zahtjeva u posebnoj parnici. U tom smislu je i ESLJP ocjenjujući postojanje povreda čl. 6. i čl. 13. Konvencije zaključio kako djelotvoran postupovni odgovor može biti zadovoljen ako pravni sustav žrtvama osigurava pravno sredstvo pred građanskim sudovima, bilo zasebno ili u vezi s pravnim sredstvom pred kaznenim sudovima (presuda u predmetu Biblija i Blažević protiv Hrvatske od 12. siječnja 2016., §101). Međutim, ako postoji više pravnih sredstava koja neka osoba može iskoristiti, ona ima pravo odabrati ono pravno sredstvo kojim se rješava njezin osnovni prigovor (presuda u predmetu Bajić protiv Hrvatske od 13. studenog 2012., §74). ESLJP u više odluka naglašava kako osiguravanje odgovarajućeg pravnog okvira za zaštitu pojedinca nije dovoljno (presuda u predmetu Remetin protiv Hrvatske od 11. prosinca 2012., §96). Pravno sredstvo ne smije postojati samo u teoriji, ono mora biti djelotvorno i u praksi, u vremenskom rasponu koji omogućuje ispitivanje predmeta bez nepotrebne odgode (presuda u predmetu Artico protiv Italije od 13. svibnja 1980., § 33).

Iako bi oba pravna puta koja su oštećeniku dostupna, u načelu mogla, ako se uspješno provedu, dovesti do ostvarivanja njegovih prava, omogućavanje da se to dogodi već u sklopu kaznenog postupka kroz jasniju normativnu podlogu i sustavno ujednačavanje sudske prakse bilo bi osobito korisno u smislu ostvarenja načela ekonomičnosti.

\section{ZAKLJUČAK}

Već smo uvodno upozorili kako oštećeniku čije je subjektivno pravo povrijeđeno ili ugroženo počinjenim kaznenim djelom treba dati primjeren položaj u kaznenom postupku. Ujedno mu je nužno omogućiti da učinkovito zaštiti svoje subjektivno pravo, odnosno ostvari svoj imovinskopravni zahtjev već u sklopu kaznenog postupka.

72 Šago i Pleić, Adhezijsko rješavanje imovinskopravnog zahtjeva u kaznenom postupku, 983.

73 Pavišić, Kazneno postupovno pravo, 133. 
Navedeno nije korisno samo za oštećenika za kojeg je ostvarivanje njegova zahtjeva u kaznenom postupku učinkovitije i jeftinije, već i ukupno za pravosuđe. Time se izbjegava potreba da zbog istoga životnog događaja sude sudovi u dva različita postupka, što dovodi i do smanjenja broja predmeta koji se ponajprije rješavaju u parničnom postupku, a ujedno se izbjegava i mogućnost donošenja kontradiktornih odluka.

S obzirom na to da je institut imovinskopravnog zahtjeva uređen odredbama ZKP-a na njega se primjenjuju norme kaznenoga postupovnog prava bez obzira na to što je u osnovi riječ o građanskom zahtjevu i što je njegov smisao i svrha različita od osnovne svrhe kaznenog postupka. Stoga je prvo ograničenje oštećenikovih prava, koje povlači za sobom brojna druga ograničenja, upravo to što oštećenik nema položaj stranke u kaznenom postupku (osim ako je u položaju oštećenika kao tužitelja) i to bez obzira na to je li podnio imovinskopravni zahtjev ili ne. Posljedično, oštećenik je ograničen u pravu na izjavljivanje pravnih lijekova protiv odluke suda, a upravo se učinkovitim preispitivanjem sudskih odluka od strane nadležnog suda na najbolji način ocjenjuje učinkovitost pružene pravne zaštite pojedinom subjektu. Oštećenik bi imao pravni interes izjaviti žalbu protiv presude i to ne samo protiv odluke o imovinskopravnom zahtjevu, već i protiv odluke u cijelosti zbog svih žalbenih razloga. To posebno zbog bitnih povreda odredaba kaznenog postupka i to u situacijama kad sud uopće ne donese odluku o njegovu imovinskopravnom zahtjevu ili čak i ako sud utvrdi da okrivljenik nije kriv za počinjenje kaznenog djela koje mu se stavlja na teret jer to onemogućava donošenje odluke o imovinskopravnom zahtjevu u kaznenom postupku. Stoga bi mu ponajprije trebalo priznati položaj stranke u kaznenom postupku i sva prava koja taj položaj nosi.

Iako se u praksi, koliko se može zaključiti analizom dostupnih odluka, priznaje pravo oštećeniku na izjavljivanje žalbe protiv odluke suda kojom se upućuje u parnicu, to bi se pitanje, a s obzirom na sadašnje zakonsko uređenje i na teorijske rasprave o tome je li riječ uistinu o odluci o imovinskopravnom zahtjevu ili ne, moglo urediti preciznije davanjem oštećeniku, ako ne položaja stranke, onda izričitog prava na podnošenje pravnog lijeka protiv odluke suda o njegovu upućivanju u parnicu, ali i kada sud uopće ne donese odluku o imovinskopravnom zahtjevu iako je on postavljen.

Dosadašnje izmjene ZKP-a pozitivan su pomak kod određivanja koje vrste zahtjeva oštećenik može postaviti te su ih tako proširile na sve zahtjeve koji se mogu podnijeti u parnici. No, istodobno su ograničile mogućnost postavljanja imovinskopravnog zahtjeva samo na osobu oštećenika, što na prvi pogled isključuje njegove i univerzalne i singularne sukcesore. Iako je mišljenje autora da i sadašnje zakonsko uređenje ne može isključiti ovlaštenje univerzalnim sukcesorima na podnošenje prijedloga za ostvarivanje imovinskopravnog zahtjeva, čak i kada ga izvorni oštećenik nije postavio (jer nije to stigao učiniti), takvo se tumačenje ne može proširiti na singularne sukcesore. Budući da je najčešće riječ o osiguravateljima koji su neposrednim oštećenicima naknadili štetu i na koje je ta tražbina prešla po sili samog zakona, autori ne vide opravdani razlog zbog kojeg bi im se uskratilo pravo da svoj imovinskopravni zahtjev koji je na njih prešao od neposredno oštećenog 
ostvaruju u kaznenom postupku. Tim više što je to moguće ako do prijenosa dođe tijekom kaznenog postupka, odnosno nakon što je neposredni oštećenik već postavio svoj imovinskopravni zahtjev. U protivnom ih se sili na vođenje parničnog postupka i onda kada za to nema nikakve potrebe. Stoga je nužna izmjena ZKP-a i uklanjanja ovog nedostatka jer umjesto da uređuje procesna prava svih osoba koje mogu podnijeti imovinskopravni zahtjev, zakon je ograničio mogućnost njegova podnošenja samo na oštećenika.

Nužno je i što više ograničiti mogućnost neodlučivanja suda u kaznenom postupku o postavljenom imovinskopravnom zahtjevu, jer je pojam znatno odugovlačenje kaznenog postupka neprecizan i omogućava njegovo različito tumačenje. ZKP ne daje, a trebao bi, odgovor na pitanje kada bi se raspravljanjem o imovinskopravnom zahtjevu znatno odugovlačio postupak, već je to stvar sudske ocjene u svakom konkretnom slučaju, iako bi trebalo preciznije ograničiti mogućnost upućivanja oštećenika na pokretanje parničnog postupka. Dodatni dokazi koje sud mora izvesti samo radi utvrđivanja visine imovinskopravnog zahtjeva najčešće nisu brojni ni toliko zahtjevni da bi opteretili kazneni postupak.

Radi osiguravanja što povoljnijeg položaja oštećenika u kaznenom postupku bilo bi poželjno razmotriti mogućnost postavljanja imovinskopravnog zahtjeva i prema trećoj osobi koja nije okrivljenik u kaznenom postupku, ali uz uvjet priznavanja toj osobi svih procesnih prava, kao što je to riješeno kod oduzimanja imovinske koristi.

Premda se Zakon o kaznenom postupku stalno mijenja i nadopunjuje te se neke izmjene odnose i na položaj oštećenika, nisu sve dovele do njegova boljeg položaja u kaznenom postupku, osobito ne u dijelu koji se odnosi na odlučivanje o imovinskopravnom zahtjevu, a neke su po našoj ocjeni, taj položaj i pogoršale. Sasvim sigurno ima dosta prostora za poboljšanje tog položaja i osobito sustavnijeg uređenja instituta imovinskopravnog zahtjeva imajući u vidu njegovu osobitost kao mješavine elemenata kaznenog i građanskog prava. Stoga bi se svakako o tome trebalo voditi računa pri nekim budućim izmjenama ZKP-a (koje se već sada najavljuju).

\section{LITERATURA:}

1. Bartulović, Željko, Povijest prava i države Povijest prava i države (I. dio-Opća povijest prava i države, Rijeka: Pravni fakultet Sveučilišta u Rijeci, 2014.

2. Bayer, Vladimir. Kazneno procesno pravo - odabrana poglavlja, Knj. 2. Povijesni razvoj kaznenog procesnog prava. Zagreb: Ministarstvo unutarnjih poslova Republike Hrvatske, 1995.

3. Crnić, Ivica. Odštetno pravo, 2. bitno izmijenjeno i dopunjeno izd. Zagreb: Zgombić i partneri, 2008.

4. Dika, Mihajlo. Građansko parnično pravo, Tužba, 6. knj. Zagreb: Narodne novine, 2009.

5. Direktiva broj 2012/29/EU Europskog parlamenta i Vijeća od 25. listopada 2012. o uspostavi minimalnih standarda za prava, potporu i zaštitu žrtava kaznenih djela te o zamjeni Okvirne odluke Vijeća 2001/220/PUP, http://eur-lex.europa.eu.

6. Direktiva broj 2014/42/EU Europskog parlamenta i Vijeća od 03. travnja 2014. o zamrzavanju i oduzimanju predmeta i imovinske koristi ostvarene kaznenim djelima u Europskoj uniji, http://eur-lex.europa.eu.

7. Grubišić, Ines. „Imovinskopravni zahtjev prema okrivljeniku odgovornoj osobi kada je kaznenim djelom pribavio imovinsku korist za pravnu osobu“. Zbornik Pravnog fakulteta 
Sveučilišta u Rijeci, br. 2 (2014): 741-760, http://pravri.uniri.hr/files/zbornik/v3522014/ grubisic.pdf.

8. Kazneni zakon Republike Hrvatske, Narodne novine, br. 125/11., 144/12., 56/15., 61/15., 101/17., 118/18., 126/19.

9. Konvencija za zaštitu ljudskih prava i temeljnih sloboda, Narodne novine, MU, br. 18/97., 6/99., 14/02., 13/03., 9/05., 1/06., 2/10.

10. Krapac, Davor, Kazneno procesno pravo, Knj. 1.: Institucije, 3. izd. Zagreb: Narodne novine, 2015.

11. Kunštek, Eduard, „Actio civilis u kaznenom postupku - prijedlog novele“. Zbornik radova, Deset godina rada Zavoda za kaznene znanosti Mošćenice Pravnog fakulteta Sveučilišta u Rijeci. Rijeka: Pravni fakultet Sveučilišta u Rijeci, 2008., 201-216, https:// www.yumpu.com/it/document/read/18209553/decennium-moztanicense.

12. Kurtović, Šefko. Opća historija države i prava, Knj. 1 i 2. Zagreb: Narodne novine, 1990.

13. Pavišić, Berislav i suradnici. Kazneno postupovno pravo. 3. izd. Rijeka: Pravni fakultet Sveučilišta u Rijeci, 2010.

14. Pavišić, Berislav. Komentar Zakona o kaznenom postupku. 5. izd. Rijeka: Žagar, 2005.

15. Presuda Europskog suda za ljudska prava od 25. lipnja 2009., Beganović protiv Hrvatske, 46423/06. http://usud.hr/hr/pregled-prakse-esljp.

16. Presuda Europskog suda za ljudska prava 23. kolovoza 2016., Brkljačić protiv Hrvatske, 11756/11. http://usud.hr/hr/pregled-prakse-esljp.

17. Presuda Europskog suda za ljudska prava od 4. lipnja 2020., Butijer protiv Hrvatske, 21126/13. http://usud.hr/hr/pregled-prakse-esljp.

18. Presuda Europskog suda za ljudska prava od 24. srpnja 2014., Remetin protiv Hrvatske, 7446/12. http://usud.hr/hr/pregled-prakse-esljp.

19. Presuda Europskog suda za ljudska prava od 12. siječnja 2016., Bilbija i Blažević protiv Hrvatske, 62870/13. http://usud.hr/hr/pregled-prakse-esljp.

20. Presuda Europskog suda za ljudska prava od 13. studenoga 2012., Bajić protiv Hrvatske, 41108/10. http://usud.hr/hr/pregled-prakse-esljp.

21. Sud Europske Unije, presuda br. C-603/19 od 01. listopada 2020, https://curia.europa.eu/.

22. Šago, Dinka i Marija Pleić. „Adhezijsko rješavanje imovinskopravnog zahtjeva u kaznenom postupku“. Zbornik Pravnog fakulteta Sveučilišta u Rijeci, br. 2 (2012): 967999, https://hrcak.srce.hr/file.

23. Triva, Siniša i Mihajlo Dika. Građansko parnično procesno pravo. Zagreb: Narodne novine, 2004.

24. Ustav Republike Hrvatske, Narodne novine, br. 56/90., 135/97., 08/98., 113/00., 124/00., 124/00., 28/01., 41/01., 55/01., 76/10., 85/10., 05/14.

25. Ustavni sud Republike Hrvatske, Odluka br. U-IIIVs-3511/2006 od 22. listopada 2008., http://usud.hr/hr/paksa-ustavnog-suda.

26. Ustavni sud Republike Hrvatske, Odluka br. U-III-4581/2013. od 20. lipnja 2017., http:// usud.hr/hr/paksa-ustavnog-suda.

27. Zakon o kaznenom postupku, Narodne novine, br. 152/08., 76/09., 80/11., 121/11., 143/12., 56/13., 145/13., 152/14., 70/17., 126/19.

28. Zakon o nasljeđivanju, Narodne novine, br. 48/03., 163/03., 35/05., 127/13., 33/15., 14/19.

29. Zakon o obveznim odnosima, Narodne novine, br. 35/05., 41/08., 125/11.,78/15., 29/18.

30. Zakon o parničnom postupku, Narodne novine, br. 53/91., 91/92., 112/99., 88/01., 117/03., 88/05., 02/07., 84/08., 96/08., 123/08., 57/11., 148/11. (pročišćeni tekst), 25/13., 89/14. i $70 / 19$.

31. Vedriš, Mladen i Petar Klarić. Građansko pravo. Opći dio, stvarno pravo, obvezno $i$ nasljedno pravo. Zagreb: Narodne novine, 2003.

32. Vrhovni sud Republike Hrvatske, Portal sudske prakse, https://sudskapraksa.csp.vsrh. hr/.- za sve odluke Vrhovnog suda Republike Hrvatske i županijskih sudova. 


\author{
Mijo Galiot* \\ Vanesa Brizić Bahun**
}

Summary

\title{
LEGAL POSITION OF INJURED PARTY IN THE ADHESION PROCEDURE
}

The paper focuses on the legal position of the injured party in the procedure initiated by a complaint seeking to join a civil action to criminal proceedings. The civil claim, as an ancillary matter of civil nature joined to criminal proceedings, is known as an adhesion procedure and represents a specific combination of criminal and civil law. The aim of conducting such procedures is to observe the principle of judicial economy, but also to avoid the duplication of proceedings in the same matter. The term and the legal nature of the mechanism itself are discussed first, followed by a thorough elaboration of some of its principal characteristics, especially as regards the question of the subjects of the procedure and the preconditions for conducting the procedure, in relation to the legal position of the injured party in the procedure, which should be more adequate bearing in mind both the legal solution and the practice of Croatian courts. For this reason, the authors propose that more attention should be given, when amending the legislation on criminal proceedings, to the injured party and the civil claim mechanism itself, which should be regulated in a more systematic manner considering its specific nature. In this regard, some contentious issues are presented in the paper, together with proposed solutions. The authors also underscore that the legal position of the injured party should be improved by granting to the injured parties all the rights that they would enjoy if they presented their claim in a lawsuit.

Keywords: injured party; civil claim; adhesion procedure; damage.

* Mijo Galiot, Ph.D., Assistant Professor, Judge of Municipal Court in Split; galiot1305@gmail. com. ORCID: https://orcid.org/0000-0003-4835-0555.

** Vanesa Brizić Bahun, dipl. iur., Judge of Municipal Civil Court in Zagreb; vanesa.brizic@ gmail.com. ORCID: https://orcid.org/0000-0003-0519-1232. 